\title{
Roots, origins and backgrounds: An analysis of their meanings in the creation of adoptive families in Sweden
}

\author{
Judith Lind
}

\section{Linköping University Post Print}

N.B.: When citing this work, cite the original article.

Original Publication:

Judith Lind, Roots, origins and backgrounds: An analysis of their meanings in the creation of adoptive families in Sweden, 2012, Childhood, (19), 1, 115-128.

http://dx.doi.org/10.1177/0907568211409077

Copyright: SAGE Publications (UK and US)

http://www.uk.sagepub.com/home.nav

Postprint available at: Linköping University Electronic Press

http://urn.kb.se/resolve?urn=urn:nbn:se:liu:diva-75848 
Manuscript-ID: CHD-10-0087 (revised manuscript)

\title{
Roots, Origins and Backgrounds - An Analysis of their Meanings in the Creation of Adoptive Families in Sweden
}

\begin{abstract}
In international conventions as well as in the national discourses of many countries, children who do not grow up with their biogenetic parents have the right to receive information about their origin. The meaning of origin in intercountry adoption, however, is not necessarily the same as in artificial donor insemination (AID). Through an analysis of the information material published by the Swedish Intercountry Adoption Authority 1972- 2004 and by discussing the often-drawn analogy between adoption and AID, the present article aims to investigate the varying meanings that have been ascribed to origin and the arguments that have been used in support of its importance.
\end{abstract}

Keywords: origin, identity, adoption, artificial reproduction

Internationally, there are several declarations that serve to protect the bonds between the child and her or his background or origin. For instance, Article 7 and 8 of the UN Convention on the Rights of the Child (UNCRC) (1989) establish the child's right "to know and be cared for by his or her parents" and the right "to preserve his or her identity including nationality, name and family relations". Article 29 states that the education of children should be directed "to the development of respect for the child's parents, his or her own cultural identity, language and values", and Article 30 claims that a child who belongs to a minority group shall not be denied the right "to enjoy his or her own culture, to profess and practice his or her own religion, or to use his or her own language”. 
The above provisions must be viewed in the light of history. One of the practices that led the drafters of the UNCRC to include Article 7 and 8 within the provisions of the Convention took place in Argentina during the 1970s and 1980s: The children of oppositional families were taken from their parents and given to childless military couples, who raised them as their own (Cerda 1990). Similarly, the articles protecting the child's right to her or his cultural identity and to enjoying her or his own culture must be understood in relation to the many examples of violations of the rights of ethnic or cultural minority groups to cultural expression and self-governance. The inspiration for these articles was hence specific transgressions, from which the UNCRC aimed to protect children. However, the child's right to know her or his parents and to preserve her or his cultural identity has to be considered by member states in relation to separations of children from their parents that are judged to be detrimental to the best interests of the child and are condemned altogether by the convention (Article 9), as well as practices such as donor aided artificial insemination (AID) and adoption, where the separation of children and birth and/or genetic parents is accepted as a fact. The latter require measures ensuring that the right of the child to know her or his origin and to preserve her or his identity will be protected despite this separation. The meaning attributed to origin and the arguments that serve to support its importance in these cases, however, are not necessarily the same as in relation to the systematic separation of children from parents belonging to ethnic minorities or a political opposition.

The present article aims to investigate the varying meanings and levels of significance that have been attributed to questions concerning roots, origins and backgrounds in a specific context: public guidance and information material on adoption in Sweden published between 1972 and 2004. The aim is not to question that knowledge and information about backgrounds and origins is indeed important, but rather to analyse what views of children and identity 
underlie such claims. In doing so, the article also seeks to address the often-drawn analogy between adoption and AID with regard to questions of origin.

There are several reasons for why Sweden serves as a particularly interesting site for such an analysis. First of all, Sweden has a long tradition of intercountry adoption, and it has long been one of the countries receiving the largest number of transnationally adopted children per capita in the world (Selman 2002). Further, Sweden's adoption experience differs from e.g. the US and the UK. Unlike these countries, Sweden has only seen a very small number of domestic adoptions since the late 1960s, which has had major consequences for how questions concerning identity and origins have been addressed. Finally, Sweden was one of the first countries to legislate against donor anonymity in AID (SFS 1984:1140).

\section{The Swedish adoption context}

The first law on intercountry adoption was passed in 1971 (SFS 1971:796). Three years later, in 1974, the Swedish Intercountry Adoption Authority (NIA) was formed. The immediate role of the NIA was to control intercountry adoptions that to date had been performed privately, and in 1979 the NIA received a mandate to issue authorization for those non-governmental organizations that sought to mediate contacts between foreign children and Swedish adoption applicants (Lindgren 2010).

After a dramatic increase in the early 1970s, the late 1980s saw a significant decrease in the number of adoption applicants and intercountry adoptions (from nearly 1789 in 1981 to 965 in 1990 (NIA informerar 2001:1, p 8)). This decrease has primarily been related to the increasing availability of fertility treatment and assisted reproduction. In 2005 the situation had changed, and there were waiting times of one to two years for many contacts in sending countries. In 
the early 2000s, transnational adoption was also the subject of considerable controversy. In 2001, a group of Swedish social scientists presented the first results from a study showing that intercountry adoptees were overrepresented in statistics on suicide, psychiatric care and criminality (Lindblad et al. 2003). In 2002, Swedish Television broadcasted two television programmes on adoption: one about the lack of support to adoptees and one about stolen children in intercountry adoption processes. The programmes were followed by an extensive critique against transnational adoption, and a governmental commission of inquiry was appointed. The commission presented its report in 2003 with the title "Adoption at what cost?" (Adoption till vilket pris?) (SOU 2003:49), which was highly critical of the economic transactions involved in intercountry adoption procedures.

Since the late 1960s, almost all adoptions in Sweden have concerned foreign-born children, and only a small number of domestic adoptions have been performed. ${ }^{\mathrm{i}}$ As a result, the number of birth parents of adopted children in Sweden is also insignificant. Any information about the birth parents' identity is held by the authorities of sending countries, and thus access to this information has to be negotiated with them. Here, any requests for information about the background of a child may be interpreted as selectivity and the wish to choose a child, or requests may clash with the desire to protect the birth mother (Lind \& Johansson 2008).

A further consequence of the small number of national adoptions in Sweden is the almost total absence of adoptions that are national and transracial. In the US and the UK, by contrast, the large numbers of transracial adoptions of black and Indian children in the late 1970s and 80s dominated the public debate on adoption. They were followed by a critique against and a subsequent ban on transracial adoption on the grounds that it constituted an attack on the African American community and that it harmed its children by denying them their heritage 
and the survival skills needed for life in a racist society (Bartholet 1991, Gaber 1994, Slaughter 2000). Subsequently, the American ban on transracial adoption was criticized on the grounds that it denied many non-White children the opportunity of permanent placement with an adoptive family. As a result, in 1994, American states and adoption agencies were no longer allowed to delay or impede an adoption by referring to the child's or the prospective adoptive parents' race, colour or national origin (Multiethnic Placement Act 1994).

The presence of ethnic minority groups from which large numbers of children were adopted by white families and the fact that these groups made claims regarding the racial and cultural identity of these children hence had a significant impact on the adoption debates in the US as well as the UK. In Sweden, on the other hand, there was no organization or other group that claimed to advocate the best interests of adopted children on the basis of shared ethnicity or race, and hence there has been little focus on the ethnic background of adopted children. Barbara Yngvesson (2010) described what she calls Sweden's multicultural challenge: “to produce an adopted citizen-subject who would be fully Swedish in thought pattern and life style but would look 'Ethiopian', 'Korean' or 'Chinese'” (p. 100).

The ethnically heterogeneous populations of the US and the UK have not only constituted the ground for transracial adoption, but they have also been a prerequisite for the racial and cultural matching of children and adoptive parents. In the Swedish context, however, with its large numbers of adoptions of children from other countries and its largely ethnically homogeneous population, the possibilities of matching in adoption are small. Therefore, the preservation of the child's identity in adoption has been given other meanings than that of cultural or ethnic matching. What meanings it has been given is one of the questions that will be addressed here. 
At the same time as the cultural background and personal experiences of the individual child came to be emphasized in favour of racial belonging in American legislation (Hollinger 2004; see Eekelaar 2004 and Ronen 2004 for similar lines of argument), the newly introduced concept of roots began to gain in importance in Sweden (Lindgren \& Lind 2009). Those adoptees who had arrived in Sweden with the first wave of intercountry adoptions in the late 1960s and early 1970s had now reached young adulthood, and several newly formed organizations for adoptees began to represent a voice in the public adoption debate. However, rather than being marked by general agreement on how the question of roots should be addressed, the Swedish debate at the beginning of the 2000s was characterized by a polarization between two different views. Some adoptees have made public claims of feeling a substantial lack of support in their efforts to find their roots and of being accused of biologism. ${ }^{\text {ii }}$ Other adoptees and researchers have cautioned against turning the search for one's roots into a norm or an ideal for all adoptees (Lena Sundström in NIA informerar 2002:1, Irhammar 1997, Brottveit 1999). At a research conference organized by NIA in 2001, the conflicting views on adoptees' roots and origins became apparent. In a review of the conference, Norwegian anthropologist Signe Howell was cited as having claimed that she did not believe that those adoptees who were interested in searching for their roots were representative of all adoptees (NIA informerar 2001:3/4). She was also quoted as having posed the question of whether "we are perhaps too eager to facilitate searches back in time" (NIA informerar 2001:3/4, p. 4). According to the review, Howell's claims were rejected by the adoptee audience and Howell herself was criticized for being naïve. Howell (2007) later argued that, what she calls, "the preoccupation with roots" among adoptees is the result of an increasing bio-centrism among 'psycho-technocrats' that can be traced to recent research in 
biotechnology, genetics and medicine and of their insistence that knowledge about one's biological origin is important to a harmonious development and sense of self.

These conflicting views mirror to some extent a tension between opposing notions of identity as either biologically given or culturally achieved, as acquired either at and through birth or through personal experience. As Cheng $(2004$, p. 69) put it “... what is it that composes our genuine, authentic personal identity? Is it our lived experience, the sum of how we each have lived? Or is it our cultural, ethnic, or racial heritage, an inherited past but not one that has been necessarily lived or experienced?" Kaja Finkler (2001) commented on the contrast between the broader societal process, in which individualism and freedom of choice are emphasized, on the one hand, and the increasing focus on bio-genetic bonds that call for connectedness and circumscription of autonomy, on the other.

\section{Data and method}

The source material for this study are the information brochures, newsletters and other documents published by the Swedish Intercountry Adoption Board (Statens nämnd för internationella adoptionsfrågor NIA) during the period 1972-2004. ${ }^{\text {iii }}$ A major part of the content of the NIA publications can be viewed as official statements and recommendations regarding adoption. NIA publications, however, also contain references to research studies, to government inquiries or to international conventions. These references and reviews are not official statements per se, but they are part of the body of information that is disseminated by the NIA and as such are included in the analysis. The NIA publications also had various recipients. Some information campaigns were aimed at the general public, others at adoptive parents and some material was aimed at social workers and other professionals working in the adoption process. Regardless of the material's intended recipients, however, much of its 
content regarding the adopted child's background, roots and origin focused on the role of adoptive parents. The publications hence contain advice to adoptive parents, descriptions of the average adoptive parent and advice to social workers on how to assess as well as advise adoptive parents. In these descriptions and advice, adoptive parents are addressed as having interests, attitudes or lack of knowledge that may be detrimental to the best interests of other parties involved in the adoption process, most notably the child.

A major methodological challenge for the present study is to investigate the changing meanings that roots, backgrounds and origins - or however we wish to refer to them - have been given, when they themselves can be signified in many different ways. To be able to trace the changing meanings that have been attributed to adoptees' roots, regardless of what words have been used, the NIA publications have been searched for all statements concerning a preadoption past - individual or collective, remembered or inherited, known or unknown.

After having identified all sections of text that qualify as such statements, these sections of text could be categorized into the following themes: Culture Shock, Discrimination, Cultural Identity, Background and Birth Parents and, lastly, Adoptee voices and Root searching. The last theme intersects to some extent with all of the previous themes. In contrast to these, however, it does not originate merely from the content of statements, but also from the context in which and by whom they were made.

\section{CUlTURE SHOCK}

In several NIA publications from the late 1970s and early 1980s, the child's migration from one country to another in intercountry adoption was said to require the child's adaptation to “an entirely new culture" (NIA 1982a, p 7. See also NIA 1985, p 5). Confrontation with this 
'entirely new culture' was claimed to lead to potential "problems of adaptation" (p 7). These problems, however, could be mitigated "if the parents received support and knowledge about the child's previous living conditions and birth culture" (p 7. See also NIA 1977 S197:7030). According to a 1977 account of how adoptive parents of Korean children were prepared for the arrival of their child, parents were furnished with information about the kind of food and sleeping arrangements their child was used to as well as a glossary of Korean words and phrases (NIA 1977 S197:7030, p 5). This detailed account, however, did not only serve to prepare adoptive parents to ease the culture chock that their child may experience, but also to explain the children's behaviour to their new parents. One example is the statement that "it is not necessarily a sign of weakness or fatigue if the child is clingy and wants to be carried a lot", as Korean children are carried on their mother's back until they are 3-4 years old (NIA 1977 S197:7030, p 5).

By addressing the issue of cultural background as one of transference, culture shock and adaptation, the birth culture was given the meaning of early experiences of a certain cultural context. According to this line of thought, as the child gained experiences of her or his new cultural context and adapted to it, s/he would leave her 'old' culture behind and become Swedish. The perception of intercountry adoptees as being as Swedish as anybody else is conveyed, for instance, in a written communication from NIA in 1981. It addressed police methods of asking persons with a foreign appearance for identification documents in order to identify illegal immigrants and stated that this procedure for intercountry adoptees "who see themselves as and are Swedish ... must be perceived as insulting” (NIA informerar 1981:1, p 13). Those involved in intercountry adoptions to Sweden in the early 1970s have later commented on the need to convince the sending countries that the children would enjoy the 
same status as children that were born in Sweden (Lindgren 2010). As a result, there was little focus on the children's non-Swedish identity.

Soon, however, the NIA publications also contained warnings that the child's transition from one culture to another was not to be pushed. In an NIA publication from 1982, child psychiatrist and adoptive mother Marianne Cederblad expressed criticism against the general attitude of many adoptive parents of wanting to "Swedishize the child" as soon as possible (Cederblad 1982, p 48). Instead, adoptive parents should be urged to show more respect for their child's identity. A recurrent theme in the advice to adoptive parents was that they should travel to their child's country of origin instead of receiving their child at a Swedish airport. Parents who did not want to travel were said to perhaps want

“ 'to be spared fatigue and stomach illness the first important days' (and instead to have all their strength left to devote themselves to painting the kid yellow and blue!)"” (NIA 1983, p 29).

Yellow and blue are the colours of the Swedish flag, and the remark is hence clearly sarcastic. It also indicates the beginning of a shift away from the colour-blind view of intercountry adoptees as being as Swedish as anybody else. As we will see, this shift was further powered by an acknowledgement of the fact that intercountry adoptees, like immigrants, were subject to racial discrimination and xenophobia.

\section{DISCRIMINATION}

Despite an increasing immigration to Sweden, its population remained ethnically and culturally fairly homogeneous throughout the $20^{\text {th }}$ century and the ideal of colour blindness, prevailed. As the 1970s turned into the 80 s, the first cohorts of intercountry adoptees grew up to become teenagers. At the same time, the Swedish political debate experienced a heightened 
awareness of the increasing "tendencies of ethnically based prejudice, discrimination and antagonism" (Proposition 1978/79:108). Immigrants were the targets of these xenophobic currents and adoptees, it was now emphasized, were immigrants too. Adoptive parents were urged to acknowledge their children's status as immigrants and to engage themselves in the fight against racism.

At first, this standpoint found expression in NIA publications through the voices of others outside the adoption community, most notably members of the discrimination inquiry. In a 1981 newsletter the commissioner of the inquiry urged adoptive parents to refrain from trying to hide their child's background (NIA informerar 1981:3, p 2). His claim - that it is important to realize and to accept that the transnationally adopted child does come from another country and that adoptive parents should acquire knowledge about that country and pass it on to their child so that s/he can feel solidarity with the country and its people - was reproduced in an NIA information brochure the following year (NIA 1982b, p 19). There it was accompanied by a photograph of an Asian girl dressed in traditional Korean clothing (See also NIA informerar 1983:1-2, p 2)

In a 1983 newsletter, it was again a member of the government appointed Discrimination Inquiry who stated that "there is always something in the ethnic identity of the adopted child sometimes a lot - that is not 'Swedish' and you cannot make that disappear" (NIA informerar 1983:1-2, p 3). He continued by saying: "The fact is that I believe that parents who deny their children's origin and need for an ethnic identity of their own are unfit" (NIA informerar 1983:1-2, p 4). The recommendations for adoptive parents to acknowledge that adoptees are indeed immigrants to Sweden and that they share many experiences with other immigrants can be interpreted as an indicator that adoptive parents hitherto had not been willing to do so. 
Supporting such an assumption are portrayals of adoptees who claim to perceive themselves as Swedish (e.g., NIA 1982b, p 7) and who want to dissociate themselves from other immigrants.

Almost ten years later, xenophobia was again the subject of a whole issue of the NIA newsletter. Again, adoptive parents were urged to "think through and be certain of their own attitude in questions concerning prejudice, immigration and discrimination" (NIA informerar 1992:2, p 3). They and their children were asked to be a "vanguard against prejudice" by not only accepting, but by celebrating the bicultural background of transnationally adopted children (NIA informerar 1992:2, p 1). This is a different approach to the cultural identity of intercountry adoptees compared to the previous emphasis on adoptees' rights to be as Swedish as anybody else. The NIA message of the early 1990s was instead "being Swedish, but also something else is enriching - for the adoptee and for others" (NIA informerar 1992:2, p 2).

As a result of the acknowledgement that many intercountry adoptees were subjected to xenophobia and racism, attention was drawn to their origins. However, despite the fact that adoptees' encounters with racism and xenophobia were the result of the geographical marks on their bodies, their otherness was framed as non-Swedishness, rather than non-whiteness.

\section{CULTURAL IDENTITY}

The early efforts of the 1970s to ease the culture chock of the child by educating prospective adoptive parents about the culture and language of their child's country of origin and reports in the early 1980s of adoptees' encounters with xenophobia and other experiences in which their Swedishness was questioned resulted in a recommendation for adoptive parents to take 
an interest in and learn as much as possible about their child's country and culture of origin. The following statement can be found in the NIA Handbook for Social Welfare Boards from 1982

"It is [...] important that parents be prepared to give the child knowledge about its country of origin, for example about the country's history, culture and religion. It can be enjoyable and also good for the child's self-esteem to have this knowledge when questions regarding its origin arise.” (NIA 1982c, p. 25)

A few years later, in the early 1990s, the claim that adoptive parents should respect and preserve their child's cultural background was no longer made in light of portrayals of adoptive parents as unwilling to do so. A 1991 information brochure for adoptees describes "most adoptive parents nowadays [as] aware of how important it is to acquire knowledge about one's background and culture" (NIA 1991, p 8. See also NIA informerar 1996:2, p. 2).

The emphasis put on the non-Swedishness of intercountry adoptees, resulting from acknowledgement of the xenophobia that many adoptees encountered, in turn led to an emphasis on adoptees' birth nationalities and cultures. An emphasis on background, however, does not necessarily refer to the child's connectedness with a cultural context that is nonSwedish. It also served to emphasise her/his connectedness with a birth family and a past that s/he does not share with her adoptive family.

\section{BACKGROUND AND BIRTH PARENTS}

Claims regarding the importance of and adoptee's rights to knowledge about their background or origin started to emerge in the NIA material in the early 1980s (e.g., NIA informerar 1981:3, p 7; NIA 1982c, NIA 1986). What precisely the words 'background' and 'origin' 
actually referred to is seldom made explicit. However, on several occasions the word 'origin' is used in conjunction with expressions like 'previous circumstances' (NIA 1985, p 5. See also NIA 1997, p 19) or 'previous life' (NIA 1982c, p. 24; NIA 1986, p. 27). One example of an implicit explanation of the meaning of the word 'origin' is the account of a return trip to Korea in a 1985 NIA newsletter, in which the participants' most important experiences of the journey were said to have been "about the children's origin". "To have seen the foster home or the orphanage or to maybe even have met a biological parent" were described as the highlights of that journey (NIA informerar 1985:4, p 3). Here, 'origin' served to refer to the birth parents as well as other persons who took care of the child and the places where s/he had stayed when s/he was little.

Even when statements concerning the importance of background in the NIA publications explicitly referred to the birth parents, they did not solely, or even primarily, refer to biological genealogy.

"All children that are left for adoption have a background. ... Someone has given birth to the child and has for some reason or another not been able to keep it. Someone has wished a better future for the child than she herself could offer, by deciding to give it up." (NIA informerar 1981:3, p 7).

In the same newsletter, all adopted children are claimed to sooner or later ask about "the specific reasons for why they were adopted". Adoptive parents are therefore called upon to "show respect for the child's early experiences and for the people in the child's home country, who saw to it that the child could have a new family" (NIA informerar 1981:3, p 8), thereby including not only birth parents, but also other persons who may have contributed to the child's individual life history. 
Another example of the emphasis that is put on the events, circumstances and decisions that led to the child's adoption is the statement that it is important to view "the mother as a real person, who has also made the decision to leave her child for adoption" (NIA 1983, p 29). The importance of addressing the question of why the adoptee came to be adopted, albeit without explicitly mentioning the birth mother, was also claimed in a newsletter from the same year. Here it is stated that social workers "have to be prepared to help foreign-born adopted children search for their origin, find out as much as possible about themselves and the reasons for why they were adopted" (NIA informerar 1983:4, p 1). Yet another example is a 1991 information brochure for young adoptees. Here, the question "why did they choose adoption for me?" was claimed to be one of the most important questions adoptees have about their birth parents (NIA 1991, p 4. See also NIA informerar 1992:4, p 4). And in an information brochure from 1996, children are said to have "the right to knowledge about their origin and about the reason for why they were left for adoption” (NIA 1996, not paginated)

The adoptee's quest for an explanation for why he or she was given up for adoption is portrayed as the main reason for the attribution of significance to the child's birth parents. This is a reason that has little to do with biological genealogy, but all the more with the individual life history of the adoptee or what Sandra Patton (2000) refers to as routes - a concept that serves to "go beyond tracking ancestors to encompass the multiple paths through which people's lives are formed" (p 18).

It is noteworthy that the need to know one's medical history is never mentioned as an argument for why birth parents are important, neither is the need to experience likeness in physical appearance or personality. Accounts of the psychological dangers of genealogical bewilderment are few as well, but there is one example. In a 1996 NIA newsletter, 
psychotherapist Lotta Landerholm claimed that it appears to be relatively certain that "access to the genetic origin is of significance for the adopted child's ability to manage the difficulties of the teenage period without these difficulties resulting in mental problems" (NIA informerar 1996: 3, p. 8). Interestingly, however, in an interview six years later, and after her book on adoption had been published, Landerholm instead assumed a meta-perspective on her previous statement and related the importance of knowledge about one's biogenetic origin to a general preoccupation in society with biology. "In our time biological relatedness and genetic knowledge are highly valued. Maybe because biology is measurable, and psychology and emotions are not.“(NIA informerar 2003:3, p 5).

With few exceptions, the statements concerning the importance for adoptees to know their origin and the reasons they came to be adopted stem from the period before the voices of actual adoptees began to be heard in the NIA material., had reached young adulthood. In the NIA publications, the coming of age those adoptees who had arrived in Sweden with the first wave of intercountry adoptions in the late 1960s and early 1970s brought about two significant additions in the 1990s. As young adults, adoptees were now addressed in information brochures. Further, adoptees were now also quoted in the same brochures. Adoptees and adoptee organization members were now also employed by the NIA and the adoption agencies, which meant that the voices of intercountry adoptees, at least to some extent, were now channelled through them (see, e.g., NIA informerar 2002:3). The question is what implications these additions had for the meanings and significance attributed to origins and backgrounds in the NIA material.

\section{AdOPTEE VoicES AND RoOT SEARCHING}


At a hearing on root searching organized by the NIA in 2002, the organization for adopted Koreans (Adopterade Koreaners Förening, AKF) presented a list of suggestions including that the birth parents of adopted children should be registered in the national registration, that intercountry adoptees should be entitled to home-language instruction and to financial aid for their root searching activities, such as return trips to the country of birth (NIA informerar 2002:2)

Whereas the 1990s saw an increasing consensus on the significance of adoptees' backgrounds and origins as well as a steady increase in the emphasis on roots in the NIA publications, the early 2000s brought conflicting views on roots. The NIA newsletters cited adoption researchers, who pointed to the necessity of accepting that not all adoptees had the same attitude towards their background and roots (child psychologist Malin Irhammar in NIA informerar 1997:3). The same message was conveyed by Norwegian anthropologist Ånund Brottveit in an NIA newsletter in 1999. (NIA informerar 1999:4). Brottveit argued that root searching had been turned into a norm or an ideal for all adoptees based on the personal experiences of a limited number of adoptees. He acknowledged that an interest in birth parents and ethnic origin must be accepted, respected and supported, but also claimed that "this kind of identity formation must not automatically be given the force of norm for all foreign born adoptees" (NIA informerar 1999:4, p 4). And in a 2002 NIA newsletter, child psychologist Elisabeth Cleve stated that she thought that there was "too much talk" about where the adopted child was from (NIA informerar 2002:4, p. 8).

The polarization of views on root searching, however, was not simply constituted by a dividing line between the views of adoptees, on one hand, and the views of adoption 
researchers (of which many were also adoptive parents), on the other. In a 2002 NIA newsletter, Korean adoptee Lena Sundström claimed to be tired of "reading about those few adoptees, who are to represent all others, and who after four months as babies in Korea and twenty-five years in Sweden still claim to feel 'home' sick. Who start Korean associations and correspond with each other just because they have almond shaped eyes and black hair." (NIA informerar 2002:1, p $6)$.

In their reply to Sundström's column, AKF members Lena-Kim Arctaedius-Svenungsson and Martin Claesson stated that, for many adoptive families, children as well as parents, the biological family seems to represent a threat and that "being curious about one's country of origin is not a sign of weakness, or depression" (NIA informerar 2002:1, p 7).

\section{Concluding discussion}

There is a myriad of ways in which roots, backgrounds and origins may be of importance to intercountry adoptees. Several adoption researchers have commented on the complexity of the relation between roots and identity (e.g., Patton 2000, Cheng 2004, Volkman 2005, Yngvesson 2005). In the publications of the Swedish Intercountry Adoption Authority, the importance that is ascribed to roots, backgrounds and origins is related to the birth parents as well as to the birth culture. The arguments in support of their importance include:

for the adoptive parents to be able to ease the child's sense of culture shock and to understand their child's behaviour when the child first arrives in the family

- $\quad$ for the adoptee to gain pride in her/his non-Swedish background and to be able to counter racial discrimination and xenophobia

- $\quad$ for the adoptee to better understand the events and decisions that led to her/his relinquishment 
- $\quad$ for the adoptee to know the details of her/his early life history.

There was little mention of adoptees' needs to know their biogenetic origin, their DNA and the dangers of genealogical bewilderment. This is not to say that, for many adoptees, it may be precisely the desire to experience a resemblance in physical appearance, personality or temperament that may result from shared DNA that drives their search for their birth parents. The fact that such a desire does not constitute an argument in the NIA publications for why birth parents are important is curious for several reasons. First, it does not support the claim that discourses on the importance of roots are dominated by bio-centrism. Also, it qualifies the accuracy of the analogy that is often drawn between adoption and AID.

In its report, the Swedish 1981 Insemination Committee compared donor insemination to adoption with respect to the involvement of a third party. Like adoptees, the committee argued, donor conceived children should have the right to knowledge about their biogenetic origin (SOU 1983:42). However, none of the arguments that were used in support of the importance of a child's origin in the NIA publications apply to AID.$^{\text {iv }}$ Donor conceived children do not experience culture shock when they arrive in their family, they do not look non-Swedish, their birth mother has not relinquished them and their early life history is not separated from that of their parents. Instead, the sole argument that can be used in support of the disclosure of donor identity is the importance for the child to know her/his genetic origin (e.g., Proposition 2001/02:89, Lagen om genetisk integritet SFS 2006:351, SOFS 2006:10). Whereas adoptive parents are encouraged to show respect for and a positive interest in their child's (known or unknown) birth parents, there are no official recommendations for how parents of donor conceived children should talk to their child about the donor. Parents of donor conceived children are urged to tell their children how they were conceived, but the 
information on the donor's identity, profession and hobbies that is kept in the records is intended for the child only. ${ }^{\mathrm{v}}$

In contrast to adoption, there are no external factors that qualify the relatedness between a donor conceived child and her/his family. Whereas the geographical marks on the body of the transracially adopted child point in the direction of the birth parents, there is nothing in the appearance of the donor conceived child that automatically qualifies her/his relatedness to her/his parents. Further, donors do not represent an ethnic minority group on behalf of whom interest groups are likely to claim their kinship with their genetic child. Neither are donor conceived children separated from their genetic parents against the will of these parents as may be the case in national adoption, which also does not construe the bond between the donor and the donor conceived child as being in need of protection. In my view, the absence of recommendations concerning what role information on the donor should play in the families of donor conceived children is a consequence of the lack of explicit arguments regarding why information on her/his genetic origin is important for the child. Only when the reasons for why such information is important are made explicit can it be used to serve the best interest of the child.

\section{References}

Barn och unga - insatser 2007 (2008). Stockholm, Socialstyrelsen.

Bartholet, E. (1991) 'Where do Black Children Belong? The Politics of Race Matching in Adoption', University of Pennsylvania Law Review 139(5): 1163-1256. 
Brottveit, Å. (1999) Utenlandsadopterte barn og unge i Norge : Oppvekstvilkår, livsbetingelser og identitetsutvikling. Diakonhjemmets högskolecenter, Oslo.

Ceder et al. (2009) “Adopterades rätt ignoreras”, Svenska Dagbladet 090802.

Cerda, J.S. (1990) 'The Draft Convention on the Rights of the Child: New Rights', Human Rights Quarterly 12(1): 115-119.

Cheng, V.J. (2004) Inauthentic. The Anxiety over Culture and Identity. New Brunswick (NJ), Rutgers University Press.

Eekelaar, J. (2004) 'Children between cultures', International Journal of Law, Policy and the Family 18 (2): 178-194.

Finkler, K. (2001) 'The Kin in the Gene. The Medicalization of Family and Kinship in American Society', Current Anthropology 42(2):235-249.

Gaber, I. (1994) 'Transracial placements in Britain: A history', in I. Gaber and J. Aldridge (eds.) In the best interests of the child. Culture, identity and transracial adoption, pp. 12-42. London: Free Association Books.

Gottlieb, C. et al. (2000) 'Disclosure of donor insemination to the child: the impact of Swedish legislation on couples' attitudes', Human Reproduction 15(9):2052-2056. 
Hague Convention on the Protection of Children and Co-operation in Respect of Intercountry Adoption (1993).

Hollinger, J. H. (2004) 'TheWhat and Why of the Multiethnic Placement Act (MEPA)' in N.

R. Cahn \& J. H. Hollinger (eds.) Families by Law. An Adoption Reader. New York \& London, New York University Press.

Howell, S. (2007) 'Imagined Kin, Place and Community: Some Paradoxes in the Transnational Movement of Children in Adoption’ in M.E. Lieu \& M. Melhuus (eds.) Holding worlds together. Ethnographies of Knowing and Belonging. New York \& Oxford: Berghahn Books.

Hübinette, T. (2002) "Koreas skingrade barn”, Dagens Nyheter Kultur 020417.

Irhammar, M. (1997) Att utforska sitt ursprung. Identitetsformande under adolescensen hos utlandsfödda adopterade. Betydelsen av biologiskt och etniskt ursprung. Lund: Studentlitteratur.

Lindgren, C. (2010) Internationell adoption i Sverige. Politik och praktik från sextiotal till nittiotal. Stockholm: MIA.

Lindgren, C. \& Lind, J. (2009) 'Resa tillbaka. Om adoption, identitet och ursprung' in J. Lind et al. (eds.) Historien, barnen och barndomarna. Linköping: Linköpings universitet. 
Patton, S. (2000) Birth Marks. Transracial Adoption in Contemporary America (New York \& London: New York University Press.

Lindblad, F. et al. (2003) Intercountry adopted children as young adults: a Swedish cohort study. Stockholm, Centrum för utvärdering av social arbete.

Melhuus, M. \& Howell, S. (2009) 'Adoption and Assisted Reproduction: One Universe of Unnatural Procreation. An Examination ofNorwegian Legislation' in J. Edwards \& C. Salazar (eds.) European Kinship in the Age of Biotechnology. New York \& Oxford: Berghahn Books.

Proposition 1978/79:108 om organisationen av verksamheten med internationella adoptioner.

Ronen, Y. (2004) 'Redefining the child's right to identity', International Journal of Law, Policy and the Family 18 (2): 147-177.

Selman, P. (2002) 'Intercountry adoption in the new millennium - the "quiet migration" revisited', Population Research and Policy Review 21(3):205-225.

SFS 1971:796 Lag om internationella rättsförhållanden rörande adoption.

SFS 1984:1140 Lag om insemination.

SFS 2006:351 Lag om genetisk integritet 
Slaughter, M.M. (2000) 'Contested Identities: The adoption of American Indian Children and the liberal state', Social and Legal Studies 9(2):227-248

SOSFS 2006:10 Socialstyrelsens föreskrifter om ändring i föreskrifterna och allmänna råden (SOSFS 2002:13) om assisterad befruktning

SOU 1983:42 Barn genom insemination.

SOU 2003:49 Adoption till vilket pris?

SOU 2009:61 Modernare adoptionsregler.

Yngvesson, B. (2005) 'Going "Home": Adoption, Loss of Bearings and the Mythology of Roots', in T.A. Volkman (ed.) Cultures of Transnational Adoption, pp. 25-48. London: Duke University Press.

Yngvesson, B. (2010) Belonging in an Adopted World. Race, Identity and Transnational Adoption. Chicago \& London: The University of Chicago Press.

Volkman, T.A. (2005) 'Embodying Chinese Culture: Transnational Adoption in North America' in T.A. Volkman (ed.) Cultures of Transnational Adoption, pp. 81-113. London: Duke University Press.

\section{Sources}


Cederblad, M. (1982) Utländska adoptivbarn som kommit till Sverige efter tre års ålder. Anpassningsprocessen under det första året i familjen. Stockholm: NIA.

NIA informerar 1980-2004.

NIA (1977) S197:7030

NIA (1982a) En kort information om internationella adoptioner. Stockholm: NIA.

NIA (1982b) Internationella adoptioner. Stockholm: NIA.

NIA (1982c) Internationella adoptioner. Handbok för socialnämnder. Stockholm: NIA.

NIA (1983) Gruppsamtal om adoption. Stockholm: NIA.

NIA (1985) Internationella adoptioner. Stockholm: NIA.

NIA (1986) Internationell adoptionshjälp. Handbok för adoptionsorganisationer. Stockholm: NIA.

NIA (1991) Adopterad från ett annat land? Stockholm: NIA.

NIA (1996) Barn behöver föräldrar. Att adoptera - ett alternativ? Stockholm: NIA. 
NIA (1997) Internationell adoptionshjälp. Handbok för adoptionsorganisationer. Stockholm:

NIA. 
${ }^{\mathrm{i}}$ During the period 1995-2007, the annual number of cases concerning national adoption handled by Swedish social welfare boards ranged from 106 to 232 . Between 12 and 26 of these cases annually concerned the adoption of children in foster care and between 13 and 22 cases annually concerned the adoption of infants (SOU 2009:61). In comparison, 15,100 children were placed in foster care in 2007 (Socialstyrelsen, Barn och unga insatser (2008), p 6.

${ }^{\text {ii }}$ In an article in Svenska Dagbladet (one of Sweden's major morning papers) signed by six intercountry adoptees, Sweden is claimed to not acknowledge the right of intercountry adoptees to information about their biological families (Ceder et al. 2009). See Hübinette (2002) for claims on accusations of biologism.

iii 2004 was the last year in which the NIA newsletter was printed. In 2006, its first electronic issue was published on the NIA website www.mia.eu. By then, NIA had been reconfigured, from a board into an authority, now called Myndigheten för internationella adoptionsfrågor MIA.

${ }^{\text {iv }}$ Melhuus and Howell (2009) note that the fact that adoption and AID "are two very different ways of coming into being" has been ignored when Norwegian legislators motivated the revocation of donor anonymity with an analogy to adoption. However, they do not further discuss the implications of these differences.

${ }^{\mathrm{v}}$ Several studies show however, that a majority of parents of donor conceived children do not share the information about their conception with the child. (See e.g. Gottlieb et al. 2000) 